\title{
Is What Low-Income Brazilians Are Eating in Popular Restaurants Contributing to Promote Their Health?
}

\author{
Alinne de Paula Carrijo, Raquel Braz Assunção Botelho, \\ Rita de Cássia Coelho de Almeida Akutsu and Renata Puppin Zandonadi *
}

Research Group in Nutritional and Nourishment Quality, Department of Nutrition, University of Brasilia, Brasilia DF 70910-900, Brazil; alinnecarrijo@yahoo.com.br (A.d.P.C.); raquelbabotelho@gmail.com (R.B.A.B.); rita.akutsu@gmail.com (R.d.C.C.d.A.A.); renatapz@yahoo.com.br (R.P.Z.)

* Correspondence: raquelbotelho@terra.com.br; Tel.: +55-61-3307-2510; Fax: +55-61-3273-3676

Received: 22 January 2018; Accepted: 5 March 2018; Published: 27 March 2018

\begin{abstract}
This study evaluates the healthfulness of the meals offered to and consumed by low-income Brazilians in Popular Restaurants (PR). It is a cross-sectional, exploratory study. The final sample includes 36 PRs, respecting the stratification criteria for each of the five Brazilian regions. To identify the quantity and quality of food consumption, consumers' meals are evaluated. The sample calculation uses a minimum of 41 consumers in each PR. Consumption evaluation is carried out by weighing and direct observation of the meal that each consumer served to his plate. Each dish of the meals had its Technical preparation files (TPF) developed by observing the production and weighing all the ingredients. Evaluations of Energy density (ED), meal's weight components and sodium composition are conducted. Plate's composition is compared to "My plate" guidelines United States Department of Agriculture (USDA). The final sample includes 1771 low-income Brazilians consumers. The plate of PRs consumers is adequate only for the "protein group" in comparison to "My plate". Rice and beans compose more than $50 \%$ of the plate's weight, as expected, since it is a Brazilian habit of consumption at lunch. Thus, grains are the major group consumed by PRs consumers. The average ED for all PRs is $1.34 \mathrm{kcal} / \mathrm{g}$. Regarding sodium content, rice and main courses presented the highest values and are classified as high, according to Food and Drug Administration (FDA). Concerning sodium, PRs are putting Brazilian low-income population at risk for chronic diseases. However, in general, PRs are good choices because they promote access to cheap and quality traditional Brazilian foods.
\end{abstract}

Keywords: low-income population; popular restaurant; lunch; energy density; nutrition

\section{Introduction}

Popular Restaurants (PR) is an assistance program created by the Brazilian Government and it is characterized as food service units that offer inexpensive and healthy meals to low-income population in Brazil [1,2]. The purpose of this program is to guarantee the social rights of feeding, consolidated by the Universal Declaration of Human Rights [3]. It is also to improve health of low-income population, since food access and choices have a substantial impact on prevention and treatment of several diseases [4-6].

In the last decades, globalization and modernization have been changing feeding habits. A consumption increase of fatty and sugary industrialized foods, with high energy density (ED) and low fiber content can be verified. Further, people have no time to prepare meals and they are frequently eating out. In Brazil, eating out represents, to low-income population, an access to snacks that are cheap, easy and fast to intake. Usually, they have inadequate nutrients and poor sanitary conditions $[2,7,8]$. This situation results an increase of chronic and foodborne diseases that are very 
common in low-income population in developing countries such as Brazil [4-6]. Besides this panorama, we have many people that do not have access to food, or to good quality meals to guarantee survival and health.

Despite the need of eating out and knowing the difficulties to access healthy food, the Brazilian government provides more than 120,000 daily meals through the PRs. In this plan, PRs have to offer access to healthy and cheap meals as well as improve cultural food habits to low-income population [2].

However, there is no report about evaluation of this social program as a tool to promote health and to guarantee food access to low-income population in the literature. Then, the aim of this study is to evaluate the healthfulness of the meals offered to and consumed by low-income Brazilians in Popular Restaurants (PR).

\section{Materials and Methods}

This research is transversal and exploratory based on direct documentation. The Research Ethics Committee (Protocol No. 0372/10) approved it.

\subsection{Sampling}

To select PRs, we used the following inclusion criteria: (i) a food service belonging to the Popular Restaurants program of the Brazilian Federal Government; (ii) signature of the Institutional Acknowledgement Agreement by the dietitian responsible for the food service; (iii) open during lunch; and (iv) service of more than 500 meals daily. Given the inclusion criteria, 65 PRs were eligible to be part of the study. From the selected population $(N)$, the sampling plan was calculated considering an error (e) of a daily meal and a level of significance $(\alpha)$ of $5 \%$ [9]. A simple random sample was estimated through the procedure "survey select" of the SAS 9.1.3 program. The final sample included 36 PRs, respecting the stratification criteria for each of the five Brazilian geographical regions.

To identify the quantity and quality of food consumption, consumers' meals were evaluated. A minimum sample of 41 consumers in each PR was necessary. The inclusion criteria were: be a frequent consumer (more than 3 times a week) and be over 18 years old. The excluding group from the sample was pregnant women because of different nutritional needs. The individuals' selection occurred while they were waiting in line to serve their meal at lunchtime (self-service). Invitations to participate occurred to the first person in line, then the 15th person, and this pattern was used until sample was completed. Participants signed the acknowledgement and agreement term and evaluation occurred during 4 days at the PRs. On the first day, participants were recruited and, on the other 3 days, their meals were weighed and evaluated. After recruitment, the same participant continued evaluation for the rest of the study. For this study, participants had to complete the three days of consumption evaluation to be qualified. Social demographic variables, sex and age groups (<21 years old, 21-30, $31-40,41-50,51-59$ and $\geq 60$ years old) were used to qualify the analyzed variables of this study.

The analyzed variables were: (i) the weight of the meal (g) of each component of the meal, e.g., main course (protein preparation offered on the menu, usually of animal origin and decisive for the selection of other items), garnish (menu item accompanying the main course, which may have as main ingredients vegetables, pasta, tubers, and cassava flour dishes), side dishes (items such as rice and beans, culturally daily consumed by the Brazilian population), salad and dessert (fruit or sweets) [10]; (ii) the portion of each component on the plate; (iii) the consumption of fruit and vegetables; (iv) the composition of garnish (pasta or vegetable) and desserts (sweets or fruits); and (v) the energy density of the meal.

\subsection{Consumption Evaluation}

The consumption evaluation was carried out by weighing and direct observation of the meal that each consumer served in his or her plate, according to the procedures proposed by Savio, Costa, Miazaki and Schmitz [11]. The meal weight was measured to relate the percentage of each dish 
preparation in the meal composition. It was important to check the meal weight on a scale to evaluate whether the observed portions of each dish were correctly described.

To evaluate the nutritional composition of the meals, we developed technical preparation files (TPF) according to the protocol proposed by Camargo and Botelho [12]. Based on the data recorded in the TPFs, the nutritional value was calculated using the information available in the Brazilian Food Composition Table [13]. When this information did not exist, we used scientific publications and labels on processed food products and then entered the information into the system database (DietWin ${ }^{\circledR}$, Porto Alegre, Brazil).

The nutritional analysis was carried out considering the Total Energy Value (TEV) (2000 kcal/day) [1] as a benchmark, following the Brazilian guideline recommendation. The Brazilian Surveillance agency uses $2000 \mathrm{kcal}$ as the energy parameter for nutrition labeling in the Brazilian products. We considered that the lunch meal should provide $40 \%$ of TEV [1]. After the calculation of the energy values of each preparation in $100 \mathrm{~g}$ of food, we calculated ED expressed in $\mathrm{kcal} / \mathrm{g}$ of food. According to the Centers for Disease Control and Prevention [14], the preparations were classified as: high energy density (4 to $9 \mathrm{kcal} / \mathrm{g})$, medium energy density (1.5 to $4 \mathrm{kcal} / \mathrm{g})$, low energy density $(0.7$ to $1.5 \mathrm{kcal} / \mathrm{g})$ and very low energy density ( 0 to $0.6 \mathrm{kcal} / \mathrm{g}$ ). The results of these analyses helped to evaluate if the PR program is promoting access to quality food and health.

For sodium evaluation, we compared the results to the Food and Drug Administration standards for sodium content of foods [15]. They considered a general rule of $5 \%$ daily value (DV) or less of sodium per serving is low; $20 \%$ DV or more is high. Additionally, FDA settles that $140 \mathrm{mg}$ of sodium or less per serving is "low sodium"; $35 \mathrm{mg}$ of sodium or less per serving is "very low sodium".

In some PRs, Salt sachets were available to consumers who could add salt to their plate before consumption. This salt addition was not measured, and this could be a possible bias of this research. Therefore, sodium results might be underestimated.

\subsection{Statistical Analysis}

Descriptive analysis was carried out by SPSS $20^{\circledR}$ software. The amount of dietary preparations' intake (in grams) and the consumption of fruits and vegetables were adjusted considering intrapersonal variability to estimate the usual consumption of individuals through MSM $^{\circledR}$ software (2012).

T-test was used for comparisons between sexes and ANOVA for comparisons among age group and sexes. It was established that $p<0.05$ was statistically significant.

\section{Results and Discussions}

The final sample included 1771 low-income Brazilians consumers (60\% male and $40 \%$ female; age range $45 \pm 17.39$ years) distributed proportionally among the PRs of the five regions of Brazil.

Healthy eating is a mix of many factors, including stage of life, preference, access to food, culture, and traditions. The PRs were created to promote access to food respecting habits and meal quality. In Brazil, lunch is the main meal and PRs are open for it from 11:00 a.m. to 2:00 p.m. to guarantee access to a greater number of consumers. Menu is the same from the time the PR opens until it closes.

According to Brazilians food habits, PR menus should include the following preparations: rice (grains), beans, main course (protein), garnish (pasta, some cooked vegetables or other carbohydrate dishes such as couscous and "farofa" (manioc flour dish)), salad and dessert [2]. It is important to highlight that all PRs offer a fixed meal composed of one protein dish (main course), one garnish, one type of rice, one type of beans, a mixed salad, and one type of dessert. Therefore, consumers only have one menu option each day they eat at the PR. Energetic value and sodium intake are related to the mean portions consumed by the population of the whole study. PRs are located in different regions, but since they are part of a governmental program, all of them have to offer an equal fixed number of dishes. They may vary the type of protein, garnish, salads and desserts, but not the number of options.

Figure 1 represents the composition of the main plate (percentage of weight) consumed by low-income Brazilians in PRs and the distribution according to recommend groups of "My plate" 
(USDA). According to "My plate" —United States Department of Agriculture (USDA) food guidethe plate should have the composition of $20 \%$ protein group; $30 \%$ grains group; $30 \%$ vegetables group; and $20 \%$ fruit. "My plate" illustrates (proportionally in the plate) groups of foods that should be present and consumed for a healthy diet.

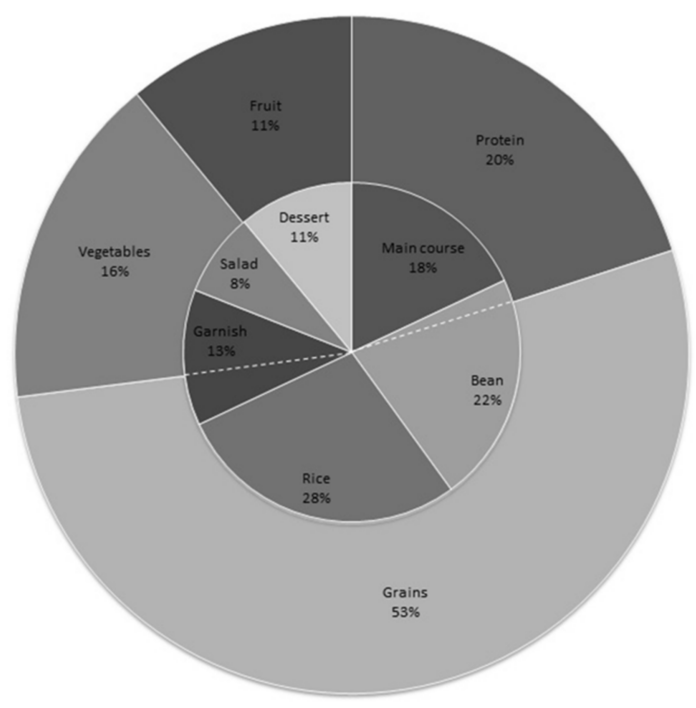

Figure 1. Plate composition by type of preparation consumed by low-income Brazilians in Popular Restaurants and distribution according to recommend groups of "My plate" United States Department of Agriculture (USDA) groups.

The PR consumers' plate is adequate only for the "protein group" in comparison to "My plate". In the USDA guide, all foods made from meat, poultry, seafood, beans, peas, eggs, and soy products are in the "protein group", which recommends 5-6 portions daily. Thus, PRs should provide 2.0-2.5 portions (40\%) of this group. In our study, PRs consumers ate about $117.88 \mathrm{~g} \pm 21.76$ of the main course (protein group) and $139.67 \mathrm{~g} \pm 48.52$ of beans. According to "My plate", beans are part of the "grains group" and "protein group". In Brazil, we consume beans with 50\% broth and $50 \%$ beans, so we have an average amount of $70 \mathrm{~g}$ of beans. Considering that beans have about $5 \%$ protein (according to the Brazilian composition table) [13], we considered this percentage as part of "protein group" and added the remaining percentage to "grains group". Therefore, at lunch, low-income Brazilians consumed about 2.5 portions of the protein group. It is important to highlight that protein/meat is the most expensive group of foods in Brazil. Probably, low-income population would not buy these products to eat at home. Thus, the highest consumption of this group at PRs is important to guarantee protein access and to promote a balanced and healthy diet during the day.

Evaluating protein group consumption, there was no statistical difference between males and females $(p=0.063)$. However, there was a significant difference among age groups: females over 60 and less than 21 years old ate less protein than the other age groups $(p<0.00)$, while males over 51 years and younger than 21 years ate less protein $(p<0.00)$.

We highlight that in our study rice and beans comprise more than $50 \%$ of the weight of the plate, which was expected since it is a Brazilian habit of consumption at lunch. Thus, grains are the major group $(53 \%)$ consumed by PRs consumers. It is almost $2 \times$ greater than "My plate" recommendation for this group. Comparing to this food guide, people need to consume 6-7 portions of grains (rice is included) daily. In Brazil, we consider that the lunch meal should provide $40 \%$ of TEV [1], so we have to guarantee 2.4-2.8 portions of grains (about $230 \mathrm{~g}$ ) at lunch. In our study, the average rice portion was $181.93 \mathrm{~g} \pm 74.93$ (Table 1) and pasta consumption (as a type of garnish) was 79.42 \pm 39.35 . We also have to include part of the beans' weight. Therefore, the grains group amount consumed at lunch in PRs was about $330 \mathrm{~g}$, more than the USDA recommendation. Table 1 shows TEV and the 
average consumption of meals, ED and sodium density (SD) of each preparation that compose the plate (in grams).

Table 1. Average and standard deviation (SD) of consumption (grams), total energetic value (TEV) Energy density (ED) and Sodium content of meals and preparations by low-income Brazilians in popular restaurants.

\begin{tabular}{|c|c|c|c|c|c|c|c|}
\hline & $\begin{array}{c}\text { Average in } \\
\text { Brazil }\end{array}$ & Rice & Bean & Main Course & Garnish & Salad & Dessert \\
\hline Meal weight \pm SD ( $g$ ) & $648.34 \pm 133.08$ & $181.93 \pm 74.93$ & $139.67 \pm 48.52$ & $117.88 \pm 21.76$ & $86.56 \pm 23.44$ & $51.70 \pm 20.47$ & $70.50 \pm 37.76$ \\
\hline $\begin{array}{l}\text { Energetic value } \pm \text { SD } \\
\quad(\mathrm{kcal})\end{array}$ & $881 \pm 222.02$ & $147.93 \pm 60.3$ & $108.80 \pm 61.20$ & $213.25 \pm 92.54$ & $151.85 \pm 133.01$ & $35.02 \pm 20.94$ & $68.60 \pm 46.90$ \\
\hline $\begin{array}{c}\text { Energy Density } \pm \text { SD } \\
(\mathrm{kcal} / \mathrm{g})\end{array}$ & $1.34 \pm 0.25$ & $1.48 \pm 0.60$ & $1.09 \pm 0.61$ & $2.13 \pm 0.93$ & $1.52 \pm 1.33$ & $0.35 \pm 0.21$ & $0.97 \pm 1.32$ \\
\hline $\begin{array}{l}\text { Sodium content } \\
\text { (mg/portion) }\end{array}$ & 2362.87 & 795.03 & 445.54 & 749.72 & 241.50 & 118.39 & 12.69 \\
\hline $\begin{array}{l}\text { Sodium Percent Daily } \\
\text { Value }(\% \mathrm{DV})\end{array}$ & 98.45 & 33.13 & 18.56 & 31.24 & 10.06 & 4.93 & 0.53 \\
\hline
\end{tabular}

The consumption of rice and beans (together) is a Brazilian habit at lunch. Barbosa [16] evaluated Brazilians food habits (2136 participants) and 94\% of Brazilian's meals showed the combination of rice and beans in their study. The amino acids combination of these two groups represents the major part of Brazilian's protein intake [17].

Despite the recommendation from the Brazilian Food Guide (BFG), [18], we observe that the consumption of rice and beans at home has been declining over time [19]. The explanation could be the reduced time to prepare food at home. Therefore, the PRs are contributing to this consumption within low-income Brazilians with low cost.

The adequate consumption of fruits and vegetables is associated to the reduction of chronic and cardiovascular diseases [20]. According to $\mathrm{WHO} / \mathrm{FAO}$, the individual recommendation of fruits and vegetables intake is about $400 \mathrm{~g}$ /day. In our study, we verified the consumption of $122.44 \mathrm{~g} \pm 33.04 \mathrm{of}$ fruits and vegetables, which represents about $30 \%$ of the daily recommendation, not the expected $40 \%$. In comparison with "My plate", fruit and vegetables should compose $50 \%$ of the graphic representation of the plate, while only $27 \%$ of this group were on the PRs plates. Men consumed more salads and vegetables than women $(p=0.000 ; p=0.003)$. When comparing groups by age, the population over 60 years and the ones younger than 21 are statistically different from the groups between 21 and 40 years $(p=0.000)$, eating less salads.

Corroborating with our data, Levy, Claro, Mondini, Sichieri and Monteiro [21] showed that the availability and the consumption of fruits and vegetables at home in Brazil is under the recommendation, contributing only $2.8 \%$ of daily TEV per person. Fruits and vegetables are very perishable and demand frequent shop and adequate storage. Therefore, it is improbable that low-income Brazilians consume large amount of these products outside of PRs to compensate low consumption there. Besides, "My plate" USDA guide recommends the plate's composition be $50 \%$ fruits and vegetables, which does not occur in meals consumed by low-income Brazilians in PRs. In this viewpoint, PRs are not providing all the needs for fruits and vegetables to promote health.

The consumption of fruits $(68.05 \mathrm{~g} \pm 47.68)$ in PRs is $2.5 \times$ higher than the offer of sweet desserts (24.40 $\mathrm{g} \pm 30.25)$. When comparing fruit consumption between male and female, there were statistical differences with higher consumption on the male group (69.18 $\mathrm{g}, p=0.026)$. Statistical differences among age groups were not observed ( $p=0.451$, female; $p=0.805$, male). It is important to highlight that the sweet desserts offered in PRs were made from fruits with sugar (such as guava paste, banana candy paste, and coconut candy). It is a very important data showing that PRs are not providing the total amount of fruits, but they are careful on planning more fruits than sweets for desserts to avoid health damage. Another relevant aspect is that in Brazil we consume higher amounts of fruits for breakfast and snack meals. Since we evaluated only lunch, it is not possible to guarantee that the fruit consumption during the day is under recommendation. 
In general, the average energy intake for low-income Brazilians in PRs lunch was $881 \mathrm{kcal}$ ( \pm 222.02$)$. There were no statistical differences among sex $(p=0.145)$. It is higher than recommended by the Brazilian Worker Food Program (WFP) of $800 \mathrm{kcal}$ [1] to guarantee adequate energy intake to maintain the organism. If the energy intake was the single parameter to guarantee health, the PRs program would be reaching its goal. However, PRs should guarantee food quality access.

The ratio of the energetic value and the weight of the meal is estimated by ED which is one of the coefficients that increases obesity and overweight or underweight on population, and foods ED affects population health [22].

The average of ED for all PRs, in this study, was $1.34 \mathrm{kcal} / \mathrm{g}( \pm 0.25)$. This value is higher than the American Institute for Cancer Research's [23] recommendation (1.25 kcal/g). The EDs shown in our study were smaller than the EDs presented by Stella [24] (1.98 kcal/g) and Canella [25] (1.43 kcal/g). The first one evaluated the ED consumption of 710 consumers in São Paulo/Brazil. Canella [25] evaluated the ED of menus offered by 21 food service in São Paulo/Brazil. ED varied among the five regions, being higher in the north $(1.51 \mathrm{kcal} / \mathrm{g} \pm 0.16)$ and lower in the south $(1.15 \mathrm{kcal} / \mathrm{g} \pm 0.12)$. Differences were not observed between the center-west region and the southeast region $(p=0.701)$. All other comparisons of ED were statistically different (all $p$ values $=0.000$ ).

Energy density as a measurement of overall diet has been the focus of many recent studies. The high-ED foods or meals are known as an "obesity-inducing dietary pattern". High ED diets are rich in fat and energy, but low in fiber, fruits and vegetables. Moreover, higher ED is inversely related to diet quality, which may encourage weight gain, increase the risk of metabolic syndrome and diabetes [26-28].

In this study, $78.1 \%$ were low ED (and 21.9\% were medium ED). Although most meals presented low ED, the average TEV is in accordance with WFP recommendation. It could be explained by the portions size of the food offered by PRs, especially rice and beans that presented low mean ED. Main courses had higher EDs. These data show that the PRs are offering meals with expected ED adequacy, contributing to prevent overweight, obesity and other chronic diseases associated to high ED food consumption. However, it is important to encourage the population to consume more fruits and vegetables for better micronutrients intake.

The Institute of Medicine has alerted to reduce salty foods [29], and the FDA set standards for the sodium content of foods [15]. They considered a general rule of $5 \%$ DV or less of sodium per serving is low; $20 \%$ DV or more is high. Additionally, FDA settles that $140 \mathrm{mg}$ of sodium or less per serving is "low sodium"; $35 \mathrm{mg}$ of sodium or less per serving is "very low sodium".

Regarding sodium content, rice and main courses presented the highest values and according to FDA are high in sodium [15]. Rice presented the highest value because it represents the biggest portion on the plate. Main courses did not represent big portions, but PRs generally use pork sausages, hot dog sausages and jerked beef that are cheap, but present high sodium content. All others are classified as medium Sodium Density, except salads and desserts groups which presented low sodium and very low sodium, respectively. It is important to emphasize that the mean sodium content at lunch meal (considering all the preparations and respective portion of the day) was about $2400 \mathrm{mg}$. This sodium amount in only one meal represents the total sodium expected for an entire day. Furthermore, the total meal sodium content might be underestimated, since the salt sachet was not considered.

\section{Conclusions}

These data are alarming, and PRs need to review their TPF to lower sodium contribution and highlight the importance of increasing the consumption of vegetables and fruits. It is also important to increase the offer of low ED foods. In some PRs, the sodium intake could be even worse if consumers added extra salt to their plates.

Concerning sodium, PRs are putting Brazilian low-income population at risk for chronic diseases, mainly cardiovascular diseases [29,30]. A better menu planning is necessary in these restaurants to guarantee sodium reduction throughout time, so the population can adjust without rejecting the new 
preparations. However, in general, the PRs are good choices for low income Brazilians because they promote access to cheap and quality Brazilian traditional foods. Better menu planning to increase fruit and vegetables offer in place of grains group is necessary. Fruits should be the only option for desserts in PRs and educational strategies are necessary to encourage more salad intake. Protein offer is adequate and it is important for this population because of its high cost. However, the negative aspect is that this protein offer is often achieved with high fat and high sodium meat sources. Low cost better option should be encouraged.

PRs contribute to promote health in low-income Brazilians overall (energy intake and macronutrients distribution). This program is a big step to guarantee Brazilians the universal right to food. However, in general, since the purpose of the program is to offer healthy food for low-income population, menu planning should be the focus of the program. PRs are good choices for low-income Brazilians because they promote access to cheap and traditional Brazilian foods, but better protein quality, more vegetable and fruits and lower sodium content are major challenges to this program.

Further studies can be developed to evaluate this population after a longer period of consumption at the PRs. Other variables such as lunch's contribution on the daily intake and the type of food acquired at home may bring new data to evaluate the program's importance to these consumers.

Author Contributions: A.d.P.C., R.B.A.B. and R.d.C.C.d.A.A. conceived and designed the experiments; A.d.P.C., R.B.A.B. and R.d.C.C.d.A.A. performed the experiments; A.d.P.C., R.B.A.B., R.P.Z. and R.d.C.C.d.A.A. analyzed the data; and A.d.P.C., R.B.A.B., R.P.Z. and R.d.C.C.d.A.A. wrote the paper.

Conflicts of Interest: The authors declare no conflict of interest. The founding sponsors had no role in the design of the study; in the collection, analyses, or interpretation of data; in the writing of the manuscript, and in the decision to publish the results.

\section{References}

1. Programa de Alimentação do Trabalhador. Portaria Interministerial nº. 66, de 25 de Agosto de 2006; Diário Oficial da União: Rio de Janeiro, Brazil. Publicada no DOU de 25 de Agosto de 2006.

2. Ministério do Desenvolvimento Social. Manual Programa Restaurantes Populares; Ministério do Desenvolvimento Social: Brasilia, Brazil, 2004.

3. General Assembly of the United Nations. Universal Declaration of Human Rights; General Assembly of the United Nations: New York, NY, USA, 1948.

4. Diez Garcia, R.W. Reflexos da globalização na cultura alimentar: Considerações sobre as mudanças na alimentação urbana. Rev. Nutr. 2003, 16, 483-492. [CrossRef]

5. Popkin, B.M.; Adair, L.S.; Ng, S.W. Global nutrition transition and the pandemic of obesity in developing countries. Nutr. Rev. 2012, 70, 3-21. [CrossRef] [PubMed]

6. Huneault, L.; Mathieu, M.È.; Tremblay, A. Globalization and modernization: An obesogenic combination. Obes. Rev. 2011, 12, e64-e72. [CrossRef] [PubMed]

7. Bezerra, I.N.; Sichieri, R. Características e gastos com alimentação fora do domicílio no Brasil. Rev. Saude Publica 2010, 44, 221-229. [CrossRef] [PubMed]

8. Lachat, C.; Nago, E.; Verstraeten, R.; Roberfroid, D.; Van Camp, J.; Kolsteren, P. Eating out of home and its association with dietary intake: A systematic review of the evidence. Obes. Rev. 2012, 13, 329-346. [CrossRef] [PubMed]

9. Cochran, W.G. Sampling Techniques; John Wiley \& Sons: Hoboken, NJ, USA, 2007.

10. Domene, S.M.Á. Técnica Dietética: Teoria e Aplicações; Guanabara Koogan: Rio de Janeiro, Brazil, 2011.

11. Savio, K.E.O.; Costa, T.H.M.D.; Miazaki, E.; Schmitz, B.D.A.S. Avaliação do almoço servido a participantes do programa de alimentação do trabalhador. Rev. Saúde Pública 2005, 39, 148-155. [CrossRef] [PubMed]

12. Camargo, E.; Botelho, R.A. Técnica Dietética: Seleção e Preparo de Alimentos-Manual de Laboratório; Atheneu: São Paulo, Brazil, 2012.

13. Lima, D. Tabela Brasileira de Composição de Alimentos-TACO; NEPA-UNICAMP: Campinas, Brazil, 2006.

14. Centers for Disease Control and Prevention. Can Eating Fruits and Vegetables Help People to Manage Their Weight? Centers for Disease Control and Prevention: Atlanta, GA, USA, 2012. 
15. Lichtenstein, A.H.; Appel, L.J.; Brands, M.; Carnethon, M.; Daniels, S.; Franch, H.A.; Franklin, B.; Kris-Etherton, P.; Harris, W.S.; Howard, B.; et al. Diet and lifestyle recommendations revision 2006: A scientific statement from the American Heart Association nutrition committee. Circulation 2016, 114, 82-96. [CrossRef] [PubMed]

16. Barbosa, L. Feijão com arroz e arroz com feijão: O Brasil no prato dos brasileiros. Horizontes Antropológicos 2007, 13, 87-116. [CrossRef]

17. Instituto Brasileiro de Geografia e Estatística. Pesquisa de Orçamentos Familiares 2008-2009: Antropometria e Estado Nutricional de Crianças, Adolescentes e Adultos no Brasil; Instituto Brasileiro de Geografia e Estatística: Rio de Janeiro, Brazil, 2010.

18. Ministério da Saúde. Guia Alimentar Para a População Brasileira: Promovendo a Alimentação Saudável; Ministério da Saúde: Brasília, Brazil, 2014.

19. Levy, R.B.; Claro, R.M.; Mondini, L.; Sichieri, R.; Monteiro, C.A. Distribuição regional e socioeconômica da disponibilidade domiciliar de alimentos no Brasil em 2008-2009. Rev. Saude Publica 2012, 46, 6-15. [CrossRef] [PubMed]

20. World Health Organization. Fruit and Vegetables for Health: Report of a Joint FAO/WHO Workshop, 1-3 September, 2004, Kobe, Japan; World Health Organization: Geneva, Switzerland, 2005.

21. Levy, R.B.; Claro, R.M.; Bandoni, D.H.; Mondini, L.; Monteiro, C.A. Availability of added sugars in Brazil: Distribution, food sources and time trends. Revista Brasileira de Epidemiologia 2012, 15, 3-12. [CrossRef] [PubMed]

22. Duffey, K.J.; Popkin, B.M. Energy density, portion size, and eating occasions: Contributions to increased energy intake in the United States, 1977-2006. PLoS Med. 2011, 8, e1001050. [CrossRef] [PubMed]

23. World Cancer Research Fund; American Institute for Cancer Research. Food, Nutrition, Physical Activity, and the Prevention of Cancer: A Global Perspective; American Institute for Cancer Research: Washington, DC, USA, 2007.

24. Stella, R.H. Densidade Energética: Relação com Variáveis Demográficas, de Estilo de Vida, Nutricionais e Socioeconômicas em Amostra Representativa da População Adulta do Município de São Paulo. Ph.D. Thesis, Universidade de São Paulo, São Paulo, Brazil, 2008.

25. Canella, D.S.; Bandoni, D.H.; Jaime, P.C. Densidade energética de refeições oferecidas em empresas inscritas no programa de alimentação do Trabalhador no município de São Paulo. Rev. Nutr. 2011, 24, 715-724. [CrossRef]

26. Rouhani, M.H.; Haghighatdoost, F.; Surkan, P.J.; Azadbakht, L. Associations between dietary energy density and obesity: A systematic review and meta-analysis of observational studies. Nutrition 2016, 32, 1037-1047. [CrossRef] [PubMed]

27. Mendoza, J.A.; Drewnowski, A.; Christakis, D.A. Dietary energy density is associated with obesity and the metabolic syndrome in US adults. Diabetes Care 2007, 30, 974-979. [CrossRef] [PubMed]

28. Wang, J.; Luben, R.; Khaw, K.-T.; Bingham, S.; Wareham, N.J.; Forouhi, N.G. Dietary energy density predicts the risk of incident type 2 diabetes the European Prospective Investigation of Cancer (EPIC)-Norfolk study. Diabetes Care 2008, 31, 2120-2125. [CrossRef] [PubMed]

29. Taylor, C.L.; Henry, J.E. Strategies to Reduce Sodium Intake in the United States; National Academies Press: Washington, DC, USA, 2010.

30. Zandonadi, R.P.; Botelho, R.B.; Rita de Cássia, C.; de Oliveira Savio, K.E.; Araújo, W.M. Sodium and health: New proposal of distribution for major meals. Health 2014, 6, 195. [CrossRef]

(C) 2018 by the authors. Licensee MDPI, Basel, Switzerland. This article is an open access article distributed under the terms and conditions of the Creative Commons Attribution (CC BY) license (http://creativecommons.org/licenses/by/4.0/). 